\title{
A Brief Review on The Effect of Nutrition/Nutritional Metabolism on Circadian Rhythm and DNA Repair in Cancer Effect of Nutrition on Circadian Rhythm and DNA Repair
}

\author{
Rümeysa Rabia KOCATÜRK ${ }^{1}$, Öznur Özge ÖZCAN ${ }^{2}$, Mesut KARAHAN ${ }^{3}$
}

\begin{abstract}
The circadian rhythm works as a clock that regulates many physiological processes including metabolism, sleep, neurobehavior, epigenetic and hormone secretion so that disruption of the circadian rhythm causes adverse effects on human health. The mutations in DNA increase the risk of developing cancer (a genetic disease caused by genome damage). Cancer formation is also caused by disruption of the circadian rhythm. Therefore, a cell's ability to properly respond to DNA damage and repair DNA is critical in preventing cancer formation. Prevention of DNA damage is important for the occurrence of cancer. Epidemiological and experimental evidence explain the variation of dietary intake effects in cancer prevalence. Dietary factors may affect the efficiency of DNA repair, their effectiveness on epigenetic mechanisms, as well as circadian rhythm and inhibit cancer formation. The purpose of this review is to reveal the effects of nutrition on circadian rhythm and DNA repair, emphasize the scarcity of existing studies, and pave the way for possible experimental studies. There are very few studies in this field, and the future studies of nutrients that affect circadian rhythm are very valuable in order to find new solutions in cancer treatment. Nutrition may have many effects on the circadian system and DNA repair, and ultimately help reduce the burden of chronic diseases.
\end{abstract}

Keywords: Cancer, Circadian rhythm, DNA repair, Nutrition

\section{Kanserde Beslenme/Beslenme Metabolizmasının \\ Sirkadiyen Ritim ve DNA Onarımına Etkisi Üzerine Kısa Bir İnceleme Beslenmenin Sirkadiyen Ritim ve DNA Onarımına Etkisi \\ Öz}

Sirkadiyen ritim, metabolizma, uyku, nörodavranış, epigenetik ve hormon salgılanması gibi birçok fizyolojik süreci düzenleyen bir saat gibi çalışır. Böylece sirkadiyen ritmin bozulması insan să̆lığı üzerinde olumsuz etkilere neden olur. DNA'daki mutasyonlar, kanserin (genom hasarının neden olduğu genetik bir hastalık) geliştirme riskini artırır. Kanser oluşumu sirkadiyen ritmin bozulmasından da kaynaklanır. Bu nedenle, bir hücrenin DNA hasarına uygun şekilde yanıt verme ve DNA'yı onarma yeteneği, kanser oluşumunu önlemede kritik öneme sahiptir. DNA hasarının önlenmesi kanserin ortaya çıkması için önemlidir.

\section{Introduction}

${ }^{1}$ Faculty of Health Sciences, Üsküdar University, Istanbul, Turkey, r_kocaturk@hotmail.com, ORCID ID: 0000-00016769-3057

${ }^{2}$ Vocational School of Health Services, Üsküdar University, Istanbul, Turkey, oznurozge.ozcan@uskudar.edu.tr, ORCID ID: 0000-0001-8992-0556

${ }^{3}$ Vocational School of Health Services, Üsküdar University, Istanbul, Turkey, mesut.karahan@uskudar.edu.tr, ORCID ID: 0000-0002-8971-678X

Corresponder author: Dr. Mesut KARAHAN, Telephone Number: +90 53595177 90, e-mail: mesut.karahan@uskudar. edu.tr ORCID ID: 0000-0002-8971-678X

Gelis Tarihi: 3 Mart 2021 Kabul Tarihi: 13 Ekim 2021

DOI: 10.17932/IAU.TFK.2018.008/tfk_v04i3001 
Epidemiyolojik ve deneysel kanıtlar, kanser prevalansında diyet alımı etkilerinin değişkenliğini açıklamaktadır. Diyet faktörleri, DNA onarımının etkinliğini, epigenetik mekanizmalar üzerindeki etkinliğini ve ayrıca sirkadiyen ritmi etkileyebilir ve kanser oluşumunu engelleyebilir. Bu derlemenin amacı beslenmenin sirkadiyen ritim ve DNA onarımı üzerindeki etkilerini ortaya koymak, mevcut çalışmaların azlığını vurgulamak ve olası deneysel çalışmaların önünü açmaktır. Bu alanda çok az çalışma vardır ve sirkadiyen ritmi etkileyen besinlerle ilgili gelecekte yapılacak çalışmalar kanser tedavisine yeni çözümler bulmak için çok değerlidir. Beslenmenin sirkadiyen sistem ve DNA onarımı için birçok etkisi ve nihayetinde kronik hastalıkların yükünü azaltmada yardımcı rolü olabilir.

Anahtar Kelimeler: Beslenme, DNA tamiri, Kanser, Sirkadiyen ritim

Cancer is the second cause of death worldwide after cardiovascular disease and shows a steady increase (1-2). In 2018, 18.078.957 new cases and 9.555.027 deaths worldwide were from cancer (3). World Health Organization reported 23.6 million new cancer cases each year by 2030 and there will be a large increase in less developed parts of the world (4). Cancer is a genetic disease caused by mutations in genes that control cellular functions, and currently, there are more than 100 different known types of cancer and $>500$ genes involved in cancer (5). Surgery, radiotherapy, and systemic therapy are also used for the treatment of cancer (2). Among these therapies, chemotherapies (a common therapeutic) are based on destroying cancerous cells by inhibiting the proliferation of them. The chemotherapies attack DNA bases intervene with the synthesis of DNA precursors, and/or mimics them, thereby stop the replication or causing errors during DNA replication. proteins that affect cell division and contribute to mutated genes and/or oncogenesis. However, human cancer and healthy cells share the same genomic structure i.e., DNAs and mainly cell metabolism. Therefore, conventional chemotherapeutic compounds that attack DNA replication or cell division in a cancer cell likewise disrupt the non-cancerous cell structure, causing harmful side effects such as gastrointestinal and bone marrow toxicity (6). In other words, radiation and chemotherapy used in cancer treatments cause DNA damage to direct cells to apoptosis or aging as a result of the DNA damage response (7). The inability of the cell to repair DNA correctly causes it to occur in a variety of clinical phenotypes, including neurodegeneration, infertility, immune deficiencies, and susceptibility to cancer (8). DNA damage has been recognized as a cause of cancer development due to mutagenic consequences (7).

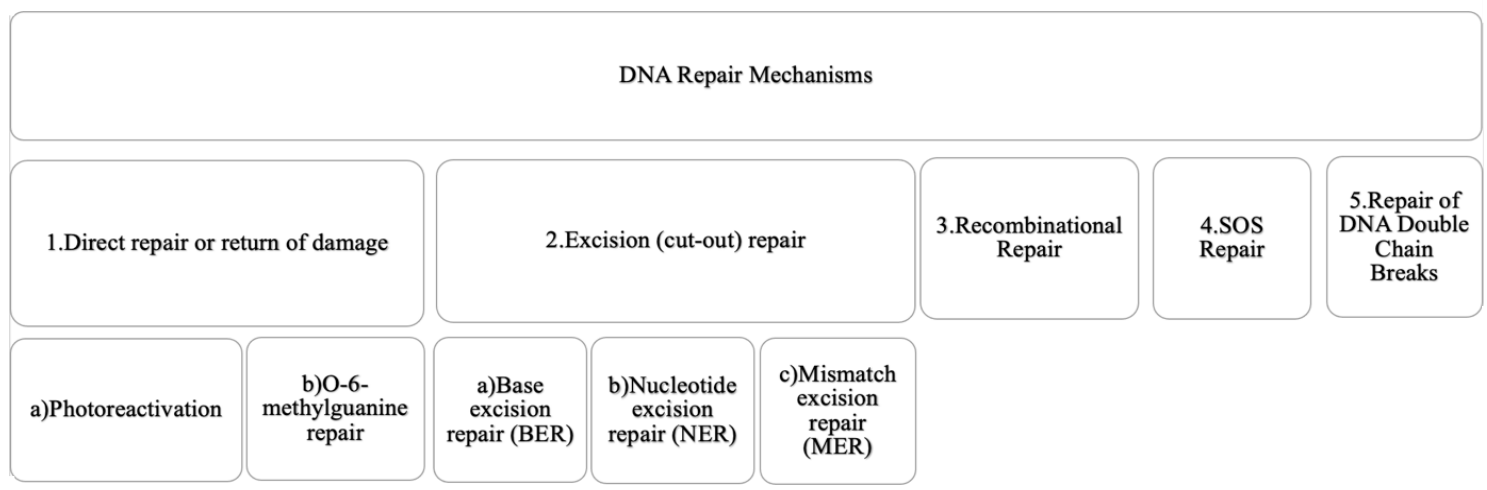

Figure 1. The diagram of DNA repair mechanisms

Cancer cells contain the resulting mutated

Our cells have complex DNA repair to protect 
genomicity (9). DNA repair is carried out according to chemically modified enzymatic activities of nuclease, helicase, polymerase, topoisomerase, recombinants, ligases, demetallizes, kinase and phosphatases. DNA repair genes are collected under two headings such as genes related to signal transmission and repair genes related to faulty mapping and repair, base, and nucleotide removal repair (9-11). DNA damage checkpoints are damaged forms of cell cycle checkpoints. DNA damage checkpoints support cell survival by preventing from entering the S-phase when DNA is damaged (G1/S checkpoint), while early lines are blocked by DNA damage (intra-S checkpoint), preventing the ignition of late replication origins. If these points fail to fulfill their role, DNA damage detection cannot be performed and cannot be corrected $(12,13)$.

Aziz Sancar discovered the role of core clock protein cryptochrome on DNA repair with his work on cryptochrome and nucleotide excision repair in 2015 and received Nobel prize (14). In one of their studies, when mice were irradiated with UV at $5 \mathrm{am}$, they developed invasive skin carcinoma at approximately five times higher frequency than mice irradiated at $5 \mathrm{pm}$ (when the repair was at maximum) (15). In a later study, early morning exposure to UV was also observed to produce maximum activation of Atr-mediated DNA damage checkpoint signaling, including activation of the tumor suppressor p53, which is the most known tumor suppressor DNA repair shows less activation early in the morning and acute responses have likely been associated with unrepaired DNA damage. Thus, these data provided the first evidence that the circadian clock plays an important role in erythemal response in skin exposed to UV radiation (16). This repair mechanism discovered by Sancar revealed that by controlling nucleotide excision repair in mice, a photolysis-like protein (cryptochrome) with no repair activity still controls repair via the circadian clock (14). Whether this repair mechanism is also effective in different types of cancer and important to support clinical studies. As a result, the effect of different epigenetic factors of UV on DNA repair should be supported by more studies.

The circadian rhythm in suprachiasmatic nucleus (SCN) is affected by external influences (nutrition, sleep, wakefulness, light, hormones, etc.) (17). Nutritional factors have many effects on the circadian clock. For example, caffeine can create time fluctuations (18) it is known that caffeine can also have role to accelerate synchronization to new time zones after jetlag (17). Moreover, aligning feeding/fasting cycles with clock-regulated metabolic changes optimizes metabolism, and studies with experimental animals showed that feeding at inappropriate times also disrupts the organization of the circadian system by adverse nutritional conditions and various stimulants, thus contributing to adverse metabolic consequences and chronic disease development (cancer, type 2 Diabetes, heart disease, etc.) (17). Vitamin B12, folate, magnesium, iron and zinc regulate DNA replication and nucleotide synthesis. Vitamin B12 and folate have roles in maintaining chromosome stability and DNA methylation. Vitamin C, vitamin E, selenium, zinc, and manganese protect from DNA oxidation. Micronutrients such as niacin, zinc, iron and magnesium are used in the detection and repair of DNA damage. DNA damage, oxidation and methylation may be interrupted in the deficiency of these micronutrient elements. For example, nutrient deficiencies increase DNA replication stress, promotes genomic instability, exacerbate the DNA damage sensibility that is caused by environmental and endogenous genotoxins and also eliminate the normal control of gene expression by epigenetic mechanisms. Macronutrient (carbohydrate, protein and lipid) deficiencies are also associated with DNA damage. For instance, severe protein calorie deficiency and excessive calorie intake, which lead to overweight/ obesity, are also associated with DNA damage $(19,20)$. From this point of view, preservation 
of nutrition sheds light on that DNA damage and circadian rhythm regulation but the effect of these three events on each other is remains unexplained. In cancer treatment, the DNA in cancer cells is degraded, and the cancerous cells are destroyed, but the DNA in healthy cells is damaged and can cause the formation of new cancer cells. Therefore, the importance of DNA repair in preventing cancer formation is remarkable. Nutrition has important effects on these factors, but there is lack of studies that explains these three important issues on cancer.

In this review, our aim is to establish the link between nutrition, DNA repair, circadian rhythm and later on to provide ideas for preclinical and clinical studies.

\section{DNA Repair and Circadian Rhythm of Cancer Cells}

Circadian rhythm and cell cycle coexist in the normal and cancer cells. Serine-threonine cyclin-dependent kinases (CDKs) regulate the transition from one phase to another in a cell. Transcriptional/translational feedback loops (TTFLs) that control circadian rhythm and cell cycle-based circadian oscillator coexist in a single cell and are regulated by CDKs. While the circadian clock is driven by systemic signals from the body and the internal energetic state of the cell, it depends on a combination of many other factors such as tumorigenic mutations, mitogenic stimulation, cell cycle progression, and DNA damage checkpoints [coupling factors: MYC (avian myelocytomatosis viral oncogene homolog), ATM/ATR, p16, p21, $\mathrm{p} 53, \mathrm{WEE} 1]$. The interaction of both oscillator based TTFLs, defined by certain matching factors, and determines the circadian timing of cell division (21). This is why DNA damage and circadian rhythm are strongly linked. Impaired synchronization between the internal clock and the metabolic rhythm affects the energy balance, increasing the risk of cancer and heart disease (22-23). It is reported that sleep quality disorders are associated with intestinal inflammation and systemic immune response. Recent studies and reviews support that circadian misalignment in patients with inflammatory bowel disease have been proposed, and future studies are needed to evaluate these clinical outcomes (13-24.)

Cancer cells choose to disrupt their circadian clock rhythms, but it is not known whether such disruption governs a selective fitness and a survival advantage. The circadian clock is a main actor in gatekeeping between an anabolic, proliferative mode and a homeostatic, survival mode (25), so, controlling the circadian clock may change the reverse cancer proliferation. According to the data obtained in a study, irregular circadian clock gene expression affects glioma progression by affecting tumor immune regulation and cell cycle. The risk model can predict glioma survival outcome (26). Also, MYC oncoprotein has a bidirectional relationship with the molecular clock in cancer. The molecular clock is responsible for circadian rhythms in most eukaryotic cells and organisms as a mechanism to adapt to light/ dark cycles. Disruption of human circadian rhythms, such as shift work, may serve as a risk factor for cancer (27). Explaining the relationship of these oncoproteins in terms of nutrition would also be good in terms of making significant progress.

\section{DNA Repair and Nutrition Biochemistry}

DNA repair ensures the continuity of the DNA replication. Apart from DNA repair and DNA metabolism, cell metabolism has an important place in the human genome $(9,11,14)$. According to a study, when cancer cells were stored in a glucose-free environment, measured intracellular glucose levels were found to be significantly lower than cells in the glucose-containing medium. Intracellular free glucose levels decreased by $31.34 \%$ to $25 \%$ $(28,29)$. Increased glucose consumption may play an important role in cancer progression. Glycolysis genes are used excessively in cancers. Therefore, understanding the molecular mechanisms that regulate aerobic glycolysis metabolic transition is very important for cancer $(30,31)$. Cancer cell metabolism is 
based on growth and proliferation and uses glucose as the main food source $(29,30)$. The effects of the diet on normal cell and cancer cell metabolism are different. The main purpose in cancer treatment is to destroy tumor cells without harming normal cells (30-32). Mizrak et al. mentioned that short-term fasting state protects the normal cell from chemotherapy effects (30). Since the circadian rhythm is disrupted in cancer patients, many sleep problems can also be observed (31). Specific feeding treatments may have good results on cancer patients by inducing DNA repair and inhibiting the cancerous cells.

Some of macronutrients, micronutrients, toxic materials and metabolic origin, UV light and ionized radiations may cause DNA damage. In cell metabolism, DNA repair, mRNA, tRNA, rRNA synthesis, protein and other biomolecules are possible by the presence of sufficient amount and variety of nutrients in the cytoplasm. Tyson and Mathers reported the amount and variety of nutritional support affecting DNA repair in malnourished individuals (20). There are many bioactive components that repair DNA in fruits and vegetables (33). The functional p53 gene and its encoded tumor-inhibiting and genomeprotecting p53 protein are required for DNA repair and clearance of non-repairable cells (apoptosis). Black seed oil (thymoquinone), brussels sprouts (sulforaphane), black grapes (resveratrol), chamomile tea (apigenin), green tea (catechins), ginger (gingerol), turmeric (curcumin) and foods containing zinc are reported to increase p53 protein synthesis (34-36). Foods that are rich in antioxidants reduce and prevent metabolic damage, DNA damage and telomere shortening. There is an inverse proportion between total antioxidant consumption taken with daily foods and transferred to cell plasma and DNA damage. Zinc functions as the cofactor of the enzyme in oxidative stress, DNA metabolism and apoptosis (35). Collins reported a carotenoidrich diet has been shown to reduce DNA damage (37). Also in the early stages of cancer- affected folate/methyl deficiency, most CpGarea methyl groups reported gradual loss in both encoded and decoding chains in hepatic DNA. After the formation of the tumor, most of the cytosine was re-acetylene. The level of p53 mRNA was increased in preneoplastic nodules and associated with hypomethylation in the encoding area. p53 mRNA decreased in tumor tissue and was associated with relative hypermethylation. This observation suggested that a diet with folate/methyl deficiency induced liver cancer by affecting methylation status of the p53 gene coding region and as a result by replacing p53 $(38,39)$. Since p53 is a transcription factor that protects DNA and regulates the cell cycle. This study showed important findings for the protection of DNA damage and DNA repair. The benefit of the folate/methyl bioactive material was a great contribution to the protection and repair of DNA damage in cancer cells. The methylenetetrahydrofolate reductase (MTHFR) C677T variant is important for genomic DNA methylation status and the gene-nutrient interaction between folate levels. Enzyme MTHFR is responsible for 5.10-methylenetetrahydrofolate irreverstor conversion for 5-methyl tetrahydrofolate ( $\mathrm{CH}_{3}$-THF). The MTHFR C677T variant encodes an enzyme that can be terminated with lower activity. Under the conditions of folate deficiency, thermally having a reduction in the formation of a $\mathrm{CH}_{3}$ (right) subjects carrying homozygote mutant allele for MTHFR (TT) 3-THF result in this subformation of S-adenosylmethionine and thus less condition methyl group $\left(\mathrm{CH}_{3}\right.$, for methylation reactions containing DNA methylation). $\mathrm{CH}_{3}$ 's reduced availability 3-THF is also reflected by reduced homocysteine remethylation and, as a result, higher total plasma homocysteine levels (40). Conversely, for $\mathrm{CH}_{3}$ synthesis, that is not affected by folate deficiency is protected for methylation reactions and for the conversion of methionine homocysteine-THF. MTHFR does not change the availability of genotype $\mathrm{CH}_{3}$ when the folate condition is sufficient- 
THF. Differences were observed in enzyme activity and the folate stores $(39,40)$. Metabolic products indicated approximate relative change in the number of metabolites between MTHFR genotypes $(39,40)$. Methionine uptake and metabolism played a role in a number of cellular functions, including redox maintenance, methylation reactions binding to folate metabolism and polyamine synthesis, thus coordinating nucleotide and redox state. Therefore, dietary methionine has an important place in cancer pathogenesis. Dietary methionine levels have a large impact on cellular methionine metabolism, making a link between nutrition and tumor cell metabolism that may allow tumor-specific metabolic sensitivities that may be affected by diet (41). Finally, nutrition affects DNA repair in cancer cells.

\section{Circadian Rhythm and DNA Repair in Nutrition}

Timing and composition of nutrition directly affect circadian rhythm by regulating both core clock output and circadian clock in peripheral tissues (42,43). Eating adequately and balanced can contribute to circadian rhythm to adjust the distribution of macronutrients in the main meals according to the appropriate hours of the day $(17,42,43)$. Energy intake at the wrong circadian time, can cause circadian deterioration and can lead to an increase in body weight. Feeding time is also an important factor that contributes to metabolic disruptions (43). Working hours, night work, night eating syndrome and sleep disorders can impair internal rhythm $(17,21)$. Some food timing and nutrient sort recommendations can be made for jet lag cases. Meals should be suitable for local time after the journey, consuming plenty of fluids to prevent dehydration. The choice a high-protein breakfast, low-protein and high-carbohydrate dinner, the lack of caffeine and alcohol during the trip are the main recommendations $(22,43)$. Since digestive problems can be seen in shift workers, it should be considered to prefer bulgur instead of fruit bread or brown bread, which is high in pulp content, fresh vegetables, and fruits $(43,44)$. Complex carbohydrates should be preferred because simple carbohydrates can cause irregularities in blood sugar $(17,43,45)$. The metabolic rate is slower at night than in the day. Therefore, individuals who have to eat at night may consume lighter foods similar to the foods consumed in breakfast $(42,43)$. Sugar should not be used in beverages such as coffee and tea that can be consumed at night in order to prevent sleepiness $(17,22,43)$. The meal consumed before the start of the shift should have rich content from protein (such as meat, milk, fish, dairy products, and eggs), essential oils (such as almonds, walnuts), complex carbohydrates (such as oats, wholemeal bread, bulgur). This is important for stable blood sugar throughout the night and for active mental functions (43). There are several nonessential diet compounds that are constantly shown to affect circadian rhythm. Alcohol is the most widely used psychoactive compound in the world and is found in many foods and beverages. Caffeine is also widely used in many societies (23). Caffeine consumption in the evening delayed the circadian rhythm and extends the time-dependent gene expression in vivo and in vitro $(18,46,47)$. Therefore, careful use of caffeine can accelerate the drift of circadian rhythm after travelling across time zones (46).

Nutrition has effects on circadian rhythm and is also related to DNA repair and cancer. Disruption of the circadian rhythm may lead to cancer and metabolic syndromes in murine studies (48). Considering this, in a study conducted to defend the hypothesis that timerestricted nutrition can reset the deteriorating circadian rhythm, protect against cancer and metabolic syndrome (48). It was assumed that intermittent fasting for consecutive days without calorie restriction would induce an anticarcinogenic proteome and key regulatory proteins of glucose and lipid metabolism. 14 participants performed intermittent fasting 
from sunrise to sunset (more than 14 hours) for 30 consecutive days and their serum was collected. 30-day intermittent fasting was associated with the circadian clock, anticancer serum proteomics signature, DNA repair, key regulatory proteins upregulated glucose and lipid metabolism, immune system, cognitive function, and cytoskeletal remodeling. Thus, it was seen as a protective serum proteome against metabolic syndrome, Alzheimer's disease, inflammation, various neuropsychiatric disorders and importantly cancer, suggesting that it may be a preventive and adjunct therapy against these diseases (48). So, timing of food consumption can be helpful to regulate circadian rhythm and protect against especially cancer and many other diseases. In a study with experimental animals, the epidermis layer provides protection from many external factors including UV radiation, which is the main cause of skin cancer and skin aging. It has been shown that restricted feeding (RF) changes the amplitude of the skin circadian clock in the epidermis layer and affects the expression of approximately $10 \%$ of the skin transcriptome. $\mathrm{RF}$ has been found to alter both the log sensitivity to UVB-induced DNA damage and the expression of the key DNA repair gene Xpa gene (49). As a result, it becomes clear that the feeding time affects the circadian rhythm and is related to DNA damage and DNA repair.

\section{Discussion and Conclusion}

Cancer diagnosis, treatment and preventive mechanisms have gained great importance. A method that can measure DNA repair and damage has been discovered by Aziz Sancar. How nutrition and circadian rhythm have an effect on DNA damage and repair in cancer can be measured by the comet assay technique measure for future studies. Azqueta et al. found that exposure to genotoxic agents does not alter base excision repair (BER) activity, in contrast, some studies reported that dietary interventions effect on BER activity.

They also reported in their study that nucleotide excision repair (NER) can be altered by exposure to genotoxic agents in preclinic studies (50). However, studies with nutrition in this area are very limited. It has also been argued that although the use of the comet assay to measure BER/NER phenotypes is promising, new studies should be conducted to further optimize their application in human biomonitoring and intervention studies.

Different nutrients were examined in some studies and their effective roles were found on the circadian rhythm. For example, natural cocoa nutrients improved locomotor activity in chronic sleep disorders (CSDs) which caused by psychophysiological stress using a mouse model characterized by impaired circadian rhythms and sleep-wake cycles. Cocoa increased hypothalamic mRNA expression of Hspa1 in control mice (encodes HSP70) which are associated with sleep regulation. However, cocoa did not induce Hspal expression in CSD35 mice (51). The effects of black ginger (Kaempferia parviflora) on disruption of circadian rhythms and expression of circadian clock genes were investigated in vivo and in vitro experiments. Results showed that K. parviflora extract prolonged circadian time, increased the amplitude of circadian rhythms, and caused phase delays in NIH3T3 cells. In particular, the components $\left(3,5,7,3^{\prime}, 4^{\prime}\right.$-Pentamethoxyflavone, 5,7,4'-trimethoxyflavone and 5,7 dimethoxyflavone) found in the content of this plant have been found to regulate circadian clock gene expression. In experimental animals, $K$. parviflora has been found to increase adaptation to experimental jet lag (6 hour phase progression). Consequently, polymethoxyflavones in $K$. parviflora can help regulate the circadian clock and reduce circadian distortion (52). It is essential to understand how diet affects epigenetic modifications and the impact of these modifications on cancer development today and in future generations. These studies may be very useful for the cancer treatment (53). 
The fact that various nutritional supplements can affect epigenetic mechanisms is important in the context of this review. In one study, a stronger modulation of epigenetic mechanisms was observed, associated with a trend towards higher immune tolerance acquisition in children with cow's milk allergy treated with L. rhamnosus GG (54). In this randomized controlled trial, young overweight women were given a $30 \%$ energy-restricted diet followed by 8 weeks of fish oil or a control supplement. The fatty acid receptor CD36 reduced DNA methylation at $\mathrm{CpG}+477$ due to energy restriction. Weight loss due to hypocaloric diet was also seen to decrease the methylation percentages of $\mathrm{CpG}$ regions in CD14, PDK4 and FADS1. However, methylation patterns of genes were only minimally affected by fish oil supplementation, found to be most relevant to attenuation of weight loss-induced reduction in CD36 methylation after adjusting for baseline body weight (55). A study in circadian clock mutant mice showed that the circadian clock maintains metabolic homeostasis by maintaining the daily rhythms of feeding and fasting and maintaining the balance between food and cellular stress responses (56).

Moreover, in a study suppression of DNA repair pathways could be used as a target for cancer treatment (57). However, suppression of DNA repair genes causes different complications in DNA and can trigger the formation of new cancers (58). For this reason, the studies should be increased, and different solutions should be brought by scientists. Throughout an organism's life, genomes are constantly threatened by external factors, endogenous insults and cellular processes that can seriously compromise genome integrity $(59,60)$. Most of cancer therapies -including chemical drugsdestroy DNA and DNA repair mechanism. The existence of many deficiencies in this area has been determined. Eliminating these deficiencies will help cure many diseases, primarily cancer (12).
Consequently, cancers caused by circadian rhythm deterioration and DNA damage constitute the main subject of this review. The occurrence of cancer due to the disruption of the circadian rhythm can be caused by insufficient DNA repair. Therefore, it can be predicted that correcting the circadian rhythm can increase DNA repair in the human body and eliminate the factors that causes cancer formation. Nutrients that can regulate the circadian rhythm and induce DNA repair. Further studies on the DNA repair and circadian rhythm of foods with cancer treatments may provide further demonstration of the molecular effects of nutrition in the field of cancer. Finding these effects may help in the creation of individual diet therapies for many cancer treatments in the future.

\section{Competing Interests}

The authors declare no competing interests.

\section{REFERENCES}

1. Roser M, Ritchie H. Cancer. Published online at OurWorldInData.org. 2015. https:// ourworldindata.org/cancer.

2. World Health Organization. Cancer Fact Sheet. https://www.who.int/news-room/factsheets/detail/cancer (Erișim: Kasım 2020).

3. World Health Organization. Global Cancer Profile 2020. https: //www. paho.org/hq/index.php?option=com docman\&view =download \& category s lug $=4-c$ ancer-country-profiles $2020 \&$ alias $=51561$-global - cancer-profile2020\&Itemid $=270 \&$ lang $=\mathrm{fr}$

4. Forman D, Bray F. The burden of cancer. In The Cancer Atlas, 2nd ed., Pp. 36-37 [A Jemal, P Vineis, F Bray, L Torre and D Forman, editors]. Atlanta, GA: American Cancer Society. 2014.

5.Pavlopoulou A, Spandidos DA, Michalopoulos I. Human cancer databases. Oncol Rep 2015;33:3-18. doi:10.3892/ or.2014.3579. 
6. Shewach DS, Kuchta RD. Introduction to cancer chemotherapeutics. Chem Rev 2009; 109;2859-2861. doi:10.1021/cr900208x.

7. Ou HL, Schumacher B. DNA damage responses and p53 in the aging process. Blood 2018; 131: 488-495. doi:10.1182/ blood-2017-07-746396.

8. Brown JS, O'Carrigan B, Jackson SP, et al. Targeting DNA Repair in Cancer: Beyond PARP Inhibitors. Cancer Discov 2017;7;2037. doi:10.1158/2159-8290.CD-16-0860.

9. Onur E, Tuğrul B, Bozyiğit F. DNA Damage and Repair Mechanisms. J Turk Clin Biochem 2009; 7:061-070.

10. Kurtoğlu E, Tekedereli I. DNA Onarım Mekanizmaları. Balıkesir Health Sci J 2015; 4;169-177.

11. Abugable AA, Morris JLM, Palminha NM, et al. repair and neurological disease: From molecular understanding to the development of diagnostics and model organisms. DNA Repair (Amst) 2019; 81;102669. doi:10.1016/j. dnarep.2019.102669.

12. Sancar A, Lindsey-Boltz LA, Gaddameedhi $\mathrm{S}$, et al. Circadian clock, cancer, and chemotherapy. Biochemistry. 2015; 54;2:11023. doi:10.1021/bi5007354.

13. Canakis A, Qazi T. Sleep and Fatigue in IBD: an Unrecognized but Important Extraintestinal Manifestation. Curr Gastroenterol Rep 2020; 22;2:8. doi:10.1007/s11894-0200746-x.

14. Sancar A. Mechanisms of DNA Repair by Photolyase and Excision Nuclease, Nobel Lecture. The Nobel Prizes. 2015. https:// www.nobelprize.org/uploads/2018/06/sancarlecture.pdf

15. Gaddameedhi S, Selby CP, Kaufmann WK, et al. Control of skin cancer by the circadian rhythm. PNAS USA 2011; 108;18790-5.

16. Gaddameedhi S, Selby CP, Kemp MG, et al. The circadian clock controls sunburn apoptosis and erythema in mouse skin. J Invest Dermatol 2015; 135;1119-27. doi:10.1038/jid.2014.508.

17. Potter GD, Cade JE, Grant PJ, et al. Nutrition and the circadian system. $\mathrm{Br} \mathrm{J}$ Nutr 2016; 116;3:434-42. doi:10.1017/ S0007114516002117.

18. Burke TM, Markwald RR, McHill AW, Chinoy ED, Snider JA, Bessman SC, Jung CM, O'Neill JS, Wright KP Jr. Effects of caffeine on the human circadian clock in vivo and in vitro. Sci Transl Med 2015; 7;305: 305ra146305ra146. doi: 10.1126/scitranslmed.aac5125.

19. Fenech MF. Dietary reference values of individual micronutrients and nutriomes for genome damage prevention: current status and a road map to the future. Am J Clin Nutr 2010; 91. doi:10.3945/ajen.2010.28674d.

20. Tyson J, Mathers JC. Dietary and genetic modulation of DNA repair in healthy human adults. Proc Nutr Soc 2007; 66;42-51. doi:10.1017/s0029665107005289.

21. Shostak A. Circadian Clock, Cell Division, and Cancer: From Molecules to Organism. Int J Mol Sci 2017; 18;873. doi:10.3390/ ijms 18040873 .

22. Feng D, Lazar MA. Clocks, metabolism, and the epigenome. Mol Cell 2012; 47;2:15867. doi:10.1016/j.molcel.2012.06.026.

23. Sherman H, Gutman R, Chapnik N, et al. Caffeine alters circadian rhythms and expression of disease and metabolic markers. Int J Biochem Cell Biol 2011; 43;5:829-38. doi:10.1016/j.biocel.2011.02.008.

24. Acosta J, Bussi IL, Esquivel M, et al. Circadian modulation of motivation in mice. Behav Brain Res 2020; 382:112471. doi:10.1016/j.bbr.2020.112471.

25. Alamoudi AA. Why do cancer cells break from host circadian rhythm? Insights from unicellular organisms. Bioessays. 2021; 43(4):e2000205. doi:10.1002/bies.202000205. 
26. Wang Z, Su G, Dai Z, et al. Circadian clock genes promote glioma progression by affecting tumour immune infiltration and tumour cell proliferation. Cell Prolif. 2021; 54(3):e12988. doi:10.1111/cpr.12988.

27. Burchett JB, Knudsen-Clark AM, Altman BJ. MYC Ran Up the Clock: The Complex Interplay between MYC and the Molecular Circadian Clock in Cancer. Int $\mathrm{J}$ Mol Sci. 2021; 22(14):7761. Published 2021 Jul 20. doi:10.3390/ijms22147761.

28. Nascimento RAS, Özel RE, Mak WH, et al. Single Cell Glucose Nanosensor Verifies Elevated Glucose Levels in Individual Cancer Cells. Nano Lett 2016; 16:1194-200. doi:10.1021/acs.nanolett.5b04495.

29. Elstrom RL, Bauer DE, Buzzai M, Karnauskas R, Harris MH, Plas DR, et al. Akt Stimulates Aerobic Glycolysis in Cancer Cells. Cancer Res 2004; 64:3892-9. doi:10.1158/0008-5472.can-03-2904.

30. Mizrak D, Akbulut H. Cancer patient and hunger. Turkish Journal of Oncology 2015.

31. Akınc1 E, Orhan F. Circadian Rhythm Sleep Disorders. Curr Approaches Psychiatry 2016; 8:178-89 doi: 10.18863 / pgy.81775.

32. Gillies RJ, Robey I, Gatenby RA. Causes and consequences of increased glucose metabolism of cancers. J Nucl Med 2008 49;Suppl: 224S-42S. doi:10.2967/jnumed.107.047258.

33. Chang J-L, Chen G, Ulrich CM, et al. DNA Damage and Repair: Fruit and Vegetable Effects in a Feeding Trial. Nutr. Cancer 2010; 62;329-35. doi:10.1080/01635580903407106.

34. Bieging KT. Unraveling mechanisms of p53-mediated tumor suppression. Nat Rev Cancer 2014; 14;359-70. doi: 10.1038/nrc3711.

35. Chasapis, C.T., Ntoupa, PS.A., Spiliopoulou, C.A. et al. Recent aspects of the effects of zinc on human health. Arch Toxicol 2020; 94;1443-60. doi:10.1007/s00204-02002702-9.
36. Qin JJ, Li X, Hunt C, Wang W, Wang H, Zhang R. Natural products targeting the p53MDM2 pathway and mutant p53: Recent advances and implications in cancer medicine. Genes Dis. 2018; 5(3):204-19. doi:10.1016/j. gendis.2018.07.002.

37. Collins AR. Carotenoids and genomic stability. Mutat Res 2001; 475;1-2:21-8. doi:10.1016/s0027-5107(01)00071-9.

38. Zapisek WF, Cronin GM, Lyn-Cook BD, Poirier LA. The onset of oncogene hypomethylation in the livers of rats fed methyl-deficient, amino acid-defined diets. Carcinogenesis 1992; 13;10:1869-72. doi:10.1093/carcin/13.10.1869.

39. Dizik M, Christman JK, Wainfan E. Alterations in expression and methylation of specific genes in livers of rats fed a cancer promoting methyl-deficient diet. Carcinogenesis. 1991; 12;7:1307-12. doi:10.1093/carcin/12.7.1307.

40. Friso S, Choi SW. Gene-nutrient interactions and DNA methylation. J Nutr 2002; 132;8 Suppl:2382S-2387S. doi:10.1093/ jn/132.8.2382S.

41. Sanderson SM, Gao X, Dai Z, et al. Methionine metabolism in health and cancer: a nexus of diet and precision medicine. Nat Rev Cancer 2019; 19;625-37. doi:10.1038/s41568019-0187-8.

42. Hastings MH, Maywood ES, Reddy AB. Two decades of circadian time. J Neuroendocrinol. 2008; 20;6:812-9. doi:10.1111/j.1365-2826.2008.01715.x.

43. Sözlü S, Nevin Ş. Circadian Rhythm, Health and Nutrition Relationship: Review. Turkiye Klinikleri J Health Sci 2017; 2;100-9. doi: 10.5336/healthsci.2015-48902.

44. Jagannath A, Taylor L, Wakaf Z, Vasudevan SR, Foster RG. The genetics of circadian rhythms, sleep and health. Hum Mol Genet 2017; 26; R2:R128-R138. doi:10.1093/hmg/ $\mathrm{ddx} 240$. 
45. Evans JA. Collective timekeeping among cells of the master circadian clock. J Endocrinol 2016; 230;1:R27-R49. doi:10.1530/JOE-160054 .

46. Pierard C, Beaumont M, Enslen M, et al. Resynchronization of hormonalrhythmsafter an eastboundflight in humans: Effects of slow-releasecaffeineand melatonin. Eur $\mathrm{J}$ ApplPhysiol 2001; 85;144-50.

47. Beaumont M, Batejat D, Pierard C, et al. Caffeineor melatonin effects on

48. Mindikoglu AL, Abdulsada MM, Jain A, et al. Intermittent fasting from dawn to sunset for 30 consecutive days is associated with anticancer proteomic signature and upregulates key regulatory proteins of glucose and lipid metabolism, circadian clock, DNA repair, cytoskeleton remodeling, immune system and cognitive function in healthy subjects. $J$ Proteom 2020; 217;103645. doi:10.1016/j. jprot.2020.103645.

49. Wang H, van Spyk E, Liu Q, Geyfman M, Salmans ML, Kumar V, et al. Time-Restricted Feeding Shifts the Skin Circadian Clock and Alters UVB-Induced DNA Damage. Cell Rep 2017; 20;1061-72. doi:10.1016/j. celrep.2017.07.022.

50. Azqueta A, Langie SAS, Boutet-Robinet E, et al. DNA repair as a human biomonitoring tool: Comet assay approaches. Mutat Res Rev Mutat Res 2019; 781;71-87. doi:10.1016/j. mrrev.2019.03.002.

51. Oishi K, Okauchi H, Yamamoto S, et al. Dietary natural cocoa ameliorates disrupted circadian rhythms in locomotor activity and sleep-wake cycles in mice with chronic sleep disorders caused by psychophysiological stress. Nutrition 2020; 75-6;110751. doi:10.1016/j. nut.2020.110751.

52. Yoshida I, Kumagai M, Ide M, et al. Polymethoxyflavones in black ginger (Kaempferia parviflora) regulate the expression of circadian clock genes. J Funct Foods 2020; 68;103900. doi:10.1016/j.jff.2020.103900.
53. Bishop K, Ferguson L. The Interaction between Epigenetics Nutrition and the Development of Cancer. Nutrients 2015; 7;922-47. doi:10.3390/nu7020922.

54. Paparo L, Nocerino R, Bruno C, et al. Randomized controlled trial on the influence of dietary intervention on epigenetic mechanisms in children with cow's milk allergy: the EPICMA study [published correction appears in Sci Rep. 2019 Jun 26;9(1):9504]. Sci Rep. 2019; 9(1):2828. Published 2019 Feb 26. doi:10.1038/s41598-019-38738-w.

55. do Amaral CL, Milagro FI, Curi R, Martínez JA. DNA methylation pattern in overweight women under an energy-restricted diet supplemented with fish oil. Biomed Res Int. 2014;2014:675021. doi:10.1155/2014/675021.

56. Chaix A, Lin T, Le HD, Chang MW, Panda S. Time-Restricted Feeding Prevents Obesity and Metabolic Syndrome in Mice Lacking a Circadian Clock. Cell Metab. 2019; 29(2):30319.e4. doi:10.1016/j.cmet.2018.08.004.

57. Helleday T, Petermann E, Lundin C, et al. DNA repair pathways as targets for cancer therapy. Nat Rev Cancer 2008; 8;193-204. doi:10.1038/nrc2342.

58. Kiwerska K, Szyfter K. DNA repair in cancer initiation, progression, and therapya double-edged sword. J Appl Genet 2019; 60;329-34. doi:10.1007/s13353-019-00516-9.

59. Jackson SP, Bartek J. The DNA-damage response in human biology and disease. Nature 2009; 461;7267:1071-78. doi:10.1038/ nature 08467 .

60. Ciccia A, Elledge SJ. The DNA Damage Response: Making It Safe to Play with Knives. Mol Cell 2010; 40;179-204. doi:10.1016/j. molcel.2010.09.019. 